\title{
'n Verkenning van die moontlikhede van 'n resepsieteoretiese benadering tot die lees van Romeine 7:7-25
}

\author{
J Botha
}

\begin{abstract}
An exploration of the possibilities of a reception theoretical approach to the reading of Romans 7:7-25

The multiplicity of interpretations of Romans 7:7-25 is well-known in Biblical scholarship. In this article the possibilities of a reception theoretical approach to the different readings of this text is explored. A brief theoretical discussion of this approach is given, focusing on the work of the German literary theorists, Hans Robert Jauss and Wolfgang Iser. When applied to the history of reception of Romans 7:7-25 it seems that Jauss's idea of the reader's 'horizon of expectations' and its influence on the interpretation of a text, is confirmed. It is pointed out how extratextual influences throughout the history had changed the interpretation of this text, starting right back in the fourth century with the controversy between Augustine and Pelagius, leading up to the differences between exegetes and sistematic theologians in our day. Some preliminary remarks on 'the reader' in Romans 7:7-25 as well as the gaps and textual strategies of this text are also made. The conclusion reached is that, although not necessarily revolutionary new, a reading of this text from the perspective of the role of the reader, definitely offers some fruitful possibilities for the understanding of New Testament epistolary literature.
\end{abstract}

\section{INLEIDEND}

Uit die geskiedenis van die interpretasie van die Nuwe Testament, is dit goed bekend dat Romeine 7:7-25'n gedeelte is waaroor die menings uiteenloop. Wie is die 'ek' waarvan daar in hierdie gedeelte sprake is? Verskillende antwoorde is deur die loop van die geskiedenis op hierdie vraag gegee en dit lyk nie of dit op hierdie stadium moontlik is om ' $n$ oplossing vir die probleem te bied wat algemene aanvaarding in die akademiese wêreld sal geniet nie (Newman 1983: 124). Tog is die bestaan van uiteenlopende interpretasies van ' $n$ teks juis ' $n$ belangrike rede om steeds intensief met daardie teks besig te bly. Al sou 'n mens 
net daarin kon slaag om die verskille te verklaar, is dit al 'n stap vorentoe. Dit is onder andere in hierdie verband wat ' $n$ resepsieteoretiese benadering moontlik nuwe lig op die probleem kan werp.

'n Kenmerk van die wetenskaplike bestudering van die Nuwe Testament in die afgelope paar dekades is dat daar al hoe meer gebruik gemaak word van insigte vanuit ander dissiplines. Trouens, Combrink (1986) skryf die ingrypende nuwe ontwikkelings in die Nuwe-Testamentiese wetenskap in die jongste verlede grootliks toe aan die bydraes wat vanuit ander dissiplines gelewer is.

Veral vanuit die Literatuurwetenskap is daar insigte en benaderings oorgeneem wat uiters waardevol vir die Nuwe-Testamentiese wetenskap is. Die hooffases in die metodologiese ontwikkeling in die Nuwe-Testamentiese wetenskap in hierdie eeu toon ook baie ooreenkoms met dié in die Literatuurwetenskap. So sou 'n mens byvoorbeeld baie sterk ooreenkomste kan aantoon tussen vroeëre genetiese verklaringsmetodes in die Literatuurwetenskap en die histories-kritiese fase in die Nuwe-Testamentiese wetenskap en ook tussen die teksimmanente fase in die Literatuurwetenskap (onder andere New Criticism en Strukturalisme) en die teksimmanente fase in die Nuwe-Testamentiese wetenskap (onder andere die Suid-Afrikaanse diskoersanalise).

Een van die heel jongste ontwikkelings in die metodologie van die Nuwe-Testamentiese wetenskap, is die toepassing van resepsieteorie op die lees van die Nuwe Testament (kyk Lategan 1984: 10-12; Fowler 1983; Du Plessis 1985). Die doel van hierdie artikel is om 'n kursoriese teoretiese oorsig te gee oor wat hierdie benadering behels en om daarna enkele verkennende opmerkings te maak oor die moontlikhede wat die begrippe-apparaat van hierdie benadering bied vir die interpretasie van Romeine 7:7-25. Ná 'n bespreking van terminologiese onderskeidings binne hierdie benadering en 'n kursoriese behandeling van enkele voorgangers en invloede, word die teorieë van Jauss en Iser bespreek. In die lig daarvan word enkele opmerkings oor die bepaalde Skrifgedeelte gemaak.

Lesergerigte benaderings tot die studie van tekste het veral in die laaste twee dekades vorm aangeneem en Lategan (1984: 10) is daarvan oortuig dat dit ' $n$ baie groot impak op die interpretasie van literatuur en kuns sal hê. Wat die teologiese hermeneutiek betref, is daar alreeds studies vanuit hierdie benadering gedoen op die narratiewe tekste van die Nuwe Testament (onder andere Du Plessis 1985; Fowler 1983). Wuellner (1985: 17) verwys in hierdie verband na die volgende studies: RM Fowler se proefskrif, Loaves and fishes (1981), F Kermode, The gene- 
sis of secrecy (1979); Susan Praeder, The narrative voyage: An analysis and interpretation of Acts 27-28 (1979); A Culpepper, Anatomy of the Fourth Gospel (1983).

Hoewel die verskillende skole van reader criticism dus reeds invloed uitgeoefen het op die studie van narratiewe materiaal, meen Wuellner (1985: 3) dat the study of New Testament epistolary literature has remained nearly completely unaffected'. 'n Belangrike studie wat egter vermeld moet word, is dié van Norman $R$ Petersen, Rediscovering Paul: Philemon and the sociology of Paul's narrative world (1985). Plaaslik is daar egter ook reeds enkele studies gedoen wat in 'n mindere of meerdere mate van 'n resepsieteoretiese benadering uitgaan - hoofsaaklik op die Brief aan die Galasiërs (kyk Cronjé 1986 en Lategan 1986). Daar sal egter nog deeglik besin moet word oor die toepasbaarheid van die begrippe van veral Iser se benadering op briefliteratuur, aangesien dit met die oog op narratiewe tekste ontwerp is. Daarom dus enkele verkennende opmerkings ten opsigte van 'n gedeelte van die Nuwe-Testamentiese briewe. Vanweë die relatiewe nuutheid van die toepassing van hierdie benadering op Nuwe-Testamentiese tekste, word daar eers 'n redelik uitvoerige teoretiese oorsig gegee.

\section{ONDERSKEIDING VAN STROMINGE BINNE RESEPSIETEORIE}

Dat ' $n$ mens in hierdie benadering noukeurig moet onderskei om verwarring te voorkom, blyk duidelik uit die volgende stelling van Suleiman (1980: 6):

Audience-orientated criticism is not one field but many, not a single widely trodden path but a multiplicity of crisscrossing, often divergent tracks that cover a vast area of the critical landscape in a pattern whose complexity dismays the brave and confounds the faint of heart.

Hierdie situasie is ook heel verstaanbaar in die lig van die feit dat lees 'n aktiwiteit is wat veels te ryk is en te veel fasette het om in ' $n$ enkele teorie uitputtend verdiskonteer te kan word.

Holub (1984: xii-xiii) gee die volgende verhelderende terminologiese onderskeidings: Die term resepsieteorie verwys na die algemene verskuiwing in belangstelling vanaf die outeur en die werk na die teks en die leser. Dit word as sambreelterm gebruik en dit omvat dus die benaderings van (1) Jauss, (2) Iser en (3) empiriese ondersoeke na 
resepsie. Die term resepsie-estetika word slegs in verband met Jauss se vroeëre teoretiese werk gebruik. Reader-response criticism, aan die ander kant, is ook 'n sambreelterm wat hoofsaaklik die Amerikaanse teorieë omvat. (Iser wat beskou word as een van die belangrikste figure in die ontwikkeling van die resepsieteorie, word egter normaalweg ook as 'n 'reader-response critic' beskou.)

Dat dit inderdaad ' $n$ wye spektrum benaderings of variasies is wat onder hierdie term tuishoort, blyk onder meer uit die verskillende indelings en sistematiserings wat daarvan gegee word. So byvoorbeeld onderskei Suleiman (1980: 7-45) ses verskillende benaderings onder die sambreelterm 'audience-orientated criticism', naamlik retories, semioties en strukturalisties, fenomenologies, subjektief en psigoanalities, sosiologies en histories, en hermeneuties. Fowler (1983: 35) gee op sy beurt ' $n$ ander baie insiggewende skematisering van benaderings in 'reader-response criticism', waaruit die wye spektrum van wat alles onder die begrip tuishoort, duidelik blyk:

1. Subjektivism: A psychological model of reading

(a) David Bleich's subjective criticism: primacy of subjectivity

(b) Normal Holland's transactive criticism: transaction between reader and text within reader's identity theme.

2. Phenomenology: An intersubjective model of reading

(a) Wolfgang Iser's phenomenological criticism: interaction between reader and text

(b) Stanley Fish's affective stylistics: text's manipulation of reader.

3. Structuralism: A social model of reading

(a) Jonathan Culler's structuralist poetics: reading conventions

(b) Stanley Fish's theory of interpretative strategies: authority of interpretative communities.

Die verskil tussen reader-response criticism en resepsieteorie is daarin geleë dat reader-response criticism 'n naam is wat agterna toegeken is aan die werk van ' $n$ aantal akademici wat weinig tot geen kontak met mekaar gehad het in die ontwikkeling van hulle insigte nie. Daarom is die benaderings wat onder hierdie term saamgegroepeer word, baie uiteenlopend van aard. Resepsieteorie, aan die ander kant, moet gesien word as 'n meer samehangende, bewuste en gesamentlike onderneming, veral gekoppel aan die Universiteit van Konstantz. Die twee benaderings word verder ook nog onderskei deur die feit dat daar (behalwe in die geval van Iser se werk), geen onderlinge beïnvloeding tussen die twee rigtings was nie. 
In hierdie artikel word daar nie op al hierdie benaderings ingegaan nie. Daar word gekonsentreer op die resepsieteorie en veral op die benaderings van Jauss en Iser.

\section{INVLOEDE EN VOORGANGERS}

Holub (1984: 13-52) bespreek vyf verskillende invloede wat die opkoms van resepsieteorie voorafgegaan en tot gevolg gehad het. Dit word vervolgens kortliks aan die orde gestel. Slegs dié aspek(te) van 'n benadering wat direk met die latere resepsieteorie verband hou, word genoem.

\subsection{Russiese Formalisme}

Vervreemding (ostranenie) word deur die leser opgemerk. Vervreemding verwys na 'n spesifieke verhouding tussen leser en teks wat die objek uit sy normale veld van waarneming verwyder. Die waarnemer bepaal die estetiese kwaliteit van die werk. Die device is die middel waarmee hierdie verskuiwings bewerk word wat vir die vervreemding of de-outomatisasie verantwoordelik is.

\subsection{Roman Ingarden}

Die leser moet die gapings in die teks konkretiseer. Hy deel die New Criticism se fokus op die werk self as primêre objek van ondersoek. Die verstaan van 'n kunswerk is 'n bewussynshandeling. Elke teks bevat gapings of onbepaaldhede wat deur die leser ingevul moet word. Konkretisering word as 'n aktiwiteit van die individuele leser gesien. 'n Belangrike kritiekpunt teen Ingarden is dat hy nie genoegsaam rekening hou met die 'always situated nature' van sowel die kunswerk as die waarnemer nie (Holub, 1984: 29).

\subsection{Praagse strukturalisme (Jan Mukarov̌sky en Felix Vodička)}

Hulle voeg die sosiologiese dimensie by wat by Ingarden ontbreek. Daar moet deeglik rekening gehou word met die kompleksiteit van die literêre werk. Kuns word gesien as 'n 'dynamic signifying system'. Elke kunswerk is (1) 'n kommunikatiewe teken en (2) beskik oor 'n outonome struktuur. Mukarov̌sky onderskei tussen (1) die artefak, (2) die 
estetiese objek en (3) die referensie van die teken. Vir vasstelling van referensie is die sosiologiese komponent onontbeerlik.

\subsection{Hans-Georg Gadamer}

Hy beklemtoon die belangrikheid van Heidegger se begrippe Vorhabe, Vorsicht en Vorgriff, asook die rol wat Vorurteil speel. Dit is alles dinge wat die leser met hom saambring wanneer hy lees. Behalwe die horison van die teks het die leser ook ' $n$ horison. Verstaan is ' $n$ versmelting van beide horisonne. Horison is ' $n$ wesenlike deel van die idee van situasie. Horison beskryf ons 'geplaastheid' in die wêreld - dit is egter nie 'n vaste posisie nie; nee, dit is iets wat saam met ons beweeg en iets waarin ons beweeg. Toepassing (Anwendung) is 'n wesenlike deel van interpretasie, dit wil sê die gespreksituasie waarin 'n mens met die teks verkeer: Die bemiddeling tussen toe en nou, tussen die ' $e k^{\prime}$ ' en die 'jy'. Jauss kry sy idee van verwagtingshorison by Gadamer se idee van die horison van die interpreteerder. Holub (1984: 45) is van oordeel dat Gadamer nie 'n sosiologiese perspektief in sy algemene teoretiese raamwerk geïntegreer het nie.

\subsection{Literatuursosiologie}

Die effek van die literêre werk behoort tot die wese van die werk: Hoe 'n werk geresepteer word, bepaal wat dit is. Bepaalde periodes in die geskiedenis het bepaalde invloede gehad op hoe literatuur geresepteer is. Die verhouding tussen die literatuursosiologie en die resepsieteorie is meer gekompliseerd as 'n blote verhouding van direkte impak of van eenvoudige oorsaak en effek.

Teen hierdie agtergrond het die resepsieteorie na vore gekom. In die ontstaan en ontwikkeling daarvan het veral twee Duitse literêre teoretici, Hans Robert Jauss en Wolfgang Iser, 'n leidende rol gespeel. Vervolgens word enkele hooftrekke van hulle werk bespreek.

\section{HANS ROBERT JAUSS}

\subsection{Algemene tipering}

Dit gaan vir Jauss hoofsaaklik oor die geskiedenis van mense se reaksies op literatuur en die implikasie daarvan vir vandag se interpretasie daarvan. 


\subsection{Vroeëre opvatting}

Die intreerede van Jauss, Literaturgeschichte als Provokation (in April 1967), is ' $n$ belangrike vertrekpunt vir die begrip resepsie-estetika soos wat dit in die sewentigerjare ontwikkel het. 'n Belangrike faset van sy argument is dat die historiese essensie van 'n kunswerk nie vasgestel kan word deur die produksie van die teks te bestudeer of deur bloot die teks te beskryf soos dit is nie. Nee, literatuur moet gesien word as 'n dialektiese proses van produksie en resepsie. Geskiedenis en estetika is verenig (Jauss 1970: 9). Dit is so omdat die eerste resepsie van 'n teks vanweë 'n vergelyking met werke wat alreeds gelees is, 'n toets vir die estetiese waarde daarvan insluit. Die historiese implikasie hiervan is duidelik: Die eerste leser word ondersteun en verryk deur 'n ketting van resepsies van geslag tot geslag, en op daardie wyse word die historiese waarde van ' $n$ werk bepaal en die estetiese waarde duidelik gemaak. Die produksie of aanbieding van die teks moet dus nie in die middelpunt staan nie, maar wel die resepsie en werking daarvan in die loop van die geskiedenis. Die werklike resepsies wat plaasgevind het, vorm die basis vir die analise van die histories verankerde kommunikasiesituasies. Nie meer die teks die staan in die middelpunt nie, maar die pragmatiese teks in die verloop van sy historiese uitlegte (kyk Senekal, 1983: 32). Daar word dus van die leeshandeling as interaksie uitgegaan. In hierdie interaksie het die leser as verwerkende subjek 'n wesenlike aandeel.

Die begrip verwagtingshorison (Erwartungshorizont) is baie belangrik. Jauss (1970: 12-13) omskryf dit as 'n intersubjektiewe sisteem of struktuur van verwagtings, 'n sisteem van verwysings, of 'n gedagtekonstruksie wat ' $n$ individuele leser na enige teks toe bring. Hy ken dus ' $n$ belangrike plek toe aan die kennis en ervaring wat die leser reeds vóór die interpretasieproses besit. Volgens Senekal (1983: 7-8) is dit veral belangrik om daarop te let $d$ at die verwagtingshorisonne van die leser aanhoudend gevorm en verander word. Daar is voortdurend 'n dinamiese spanning tussen werk en norm, tussen die historiese reeks literêre werke enersyds en die reeks veranderende norme of instellings van die leser(s) andersyds. In die resepsie van Romeine 7:14-25 deur die loop van die eeue word hierdie saak baie duidelik geillustreer (kyk 8.1 hieronder). Die ontvangs van 'n teks is ook nie 'n willekeurige reeks van blote subjektiewe indrukke nie. Dit is die voltrekking van spesifieke aanwysings in 'n proses van gerigte waarneming. 


\subsection{Latere opvatting}

Later het Jauss wegbeweeg van die resepsie-estetika en ook wegbeweeg van die konsep van die verwagtingshorison. Dit is veral toe te skryf aan sy reaksie teen die 'estetika van negatiwiteit': Hoe kan 'n positiewe sosiale funksie aan 'n kunswerk toegeken word as die kunswerk die gemeenskap waarin dit ontstaan, negativeer? Die idee van 'n resepsieteorie wat gebaseer is op die deurbreking van die horisonne van verwagting, was dus nie meer vir hom so aantreklik nie. Hy het toe meer begin praat van die genot (Genuss) van die literêre ervaring. Die twee elemente van Genuss is (1) onvoorwaardelike oorgawe aan die objek en (2) die inneem van 'n posisie wat die bestaan van die objek in hakies plaas en dit dus omvorm tot 'n estetiese objek. Hier kom die begrip van 'afstandskepping' ter sprake: Dit is 'n skeppende aktiwiteit van die bewussyn wat in werking tree deur die afstand wat tussen die waarnemers en die objek geskep word (Holub 1984: 69-74).

Daar is drie basiese kategorieë van die estetiese genot: (1) poiēsis - dit is die produktiewe aspek van die estetiese ervaring, die plesier wat voortvloei uit die leser se eie kreatiewe vermoëns (die leser is kreatief besig en nie bloot nabootsend nie); (2) aisthēsis - dit verwys na die 'ontvangs'-gedeelte van die estetiese ervaring; en (3) katharsis - dit word verstaan as die kommunikatiewe komponent tussen kuns en ontvanger. Hier is daar vyf patrone van interaksie, naamlik assosiatiewe identifikasie, bewonderende identifikasie, simpatiese identifikasie, katarsiese identifikasie en ironie (Holub 1984: 75-82).

Samehangend hiermee het Jauss ' $n$ sogenaamde 'drielesingteorie' daargestel, naamlik 'n eerste esteties-waarnemende leesfase, ' $n$ tweede retrospektief-interpreterende fase en 'n derde historie-applikatiewe fase (Van den Berg 1986: 1). Juis die estetiese karakter van die literêre teks dien as hermeneutiese brug wat die historiese teks oor tydsgrense heen steeds vir teenswoordige begrip toeganklik maak. Die toepassing van hierdie model op die lees van 'n teks verloop in die volgende drie fases: (1) Eerste lesing = verstaan: Die waarneem van dit wat daar geskryf staan, die bou en struktuur van die teks, die vervuldheid/onvervuldheid van die vorm, met een woord gesê, die estetiese ervaring ten opsigte van inhoud en vorm. (2) Tweede lesing = uitleg: Om die samehangende betekenis van die verskillende elemente te rekonstrueer sonder om die intensionaliteit (Sinnhorizont) van die teks te oorskry. Dit geskied deur die vra van formele vrae. (3) Derde lesing = toepassing: Die konkretisering van die betekenis as antwoord op die vrae wat gestel is, en indien nodig, die rekonstruering van die destydse horison 
en 'n vergelyking daarvan met die huidige (kyk Van den Berg 1986: 6).

Soos reeds gesê, kan die model nie sonder meer presies net so op die teks van die Nuwe Testament van toepassing gemaak word nie. Of die eerste en tweede fases werklik twee fases is, sou ' $n$ mens ook kon bevraagteken. Tog is hier momente wat nuttig kan wees vir die interpretasie van die Nuwe Testament. Veral ten opsigte van die plek wat Jauss in die derde fase aan horisonverandering gee, is baie belangrik. Gedurende die derde lesing moet die primêre literêre konteks, die historiese resepsie, gerekonstrueer word om te kan bepaal wat die teks destyds gesê het en wat dit vandag nog sê. Daar moet gevra word wat die verwagtingshorison van die kontemporêre lesers tydens die eerste publikasie van die teks was, hoe die literêre tradisie en historiese en maatskaplike situasie was, watter verwagtings die teks moontlik vervul of genegeer het en veral ook, wat die verdere verloop van die resepsie van die teks tot en met vandag was. Deur dit te doen vind daar ' $n$ verantwoordbare afbakening van verwagtingshorisonne plaas en word die afstand tussen resepsie en werking (soos in die eerste en tweede lesing blootgelê), die destydse en huidige verstaan, sigbaar. Deur te let op die horisonverandering word daar aan die probleem ontkom dat 'n teks ò teen sy historiese agtergrond ò teen die agtergrond van die huidige verwagtingshorison geïnterpreteer word. Dit het ook die verdere voordeel dat die horisonne tegelykertyd uitmekaar gehou word (Van den Berg 1986: 8). Deur die destydse en huidige horisonne uitdruklik te kontrasteer, kan die teks in sy oudheid (Alterität) gewaardeer word. Teen die agtergrond van die vrae waarop die teks in sy tyd antwoorde gebied het, kan geldige vrae ten opsigte van die betekenis van die teks vir die huidige tyd geformuleer word. Verkennende opmerkings oor die nut van 'n beskrywing van die horisonverandering en die invloed daarvan op die resepsiegeskiedenis van Romeine 7, word in 8.1 hieronder gemaak.

\subsection{Verskille tussen Jauss en Iser}

Tussen Jauss en Iser bestaan daar heelwat verskille, al kom hulle uit dieselfde skool. Voordat die teorie van Iser aan die orde gestel word, word enkele van die verskille hier aangestip:

Jauss

Uit Romantiek, begin met literêre geskiedenis.
Iser

Uit Engelese literatuurstudie, veral New Criticism en narrative theory. 
Werk hermeneuties (beïnvloed deur Gadamer).

Hou hom besig met breë sosiologiese en historiese kwessies, gebruik tekste bloot illustratief.

Besig met die makrokosmos van literatuur.
Werk fenomenologies beïnvloed deur Ingarden.

Konsentreer op die inviduele teks en hoe die leser daarop (moet) reageer.

Besig met die mikrokosmos van literatuur.

\section{WOLFGANG ISER}

\subsection{Algemene tipering}

Iser konsentreer op die fenomenologiese aard van tekstuele kommunikasie en wil dus probeer beskryf hoe die leesproses lyk en hoe dit werk. Betekenis is die resultaat van die interaksie tussen teks en leser. Dit is ' $n$ effek wat ervaar moet word en nie 'n objek wat gedefinieer moet word nie (Iser 1978: 10). Die fokus verskuif vanaf die teks as objek na die leeshandeling as proses.

Volgens Iser (1978: 18) is daar drie sake wat bestudeer moet word:

1. Die teks in sy potensiaal om die produksie van betekenis toe te laat en te manipuleer. (Hy het dus dieselfde teksbeskouing as Ingarden: Die teks is "n skelet van geskematiseerde aspekte' wat deur die leser gekonkretiseer moet word.)

2. Die prosessering van die teks in die leesproses. Van groot belang hier is die mental images (gedagtebeelde) wat gevorm word in die poging om 'n samehangende estetiese objek te konstrueer.

3. Die kommunikatiewe struktuur van literatuur om die voorwaardes te kan ondersoek wat aanleiding gee tot die teks-leserinteraksie en wat dit reguleer.

\subsection{Enkele begrippe in Iser se benadering}

\subsubsection{Die implisiete leser}

Die implisiete leser is sowel ' $n$ tekstuele gegewe as ' $n$ proses van betekenisproduksie: 'The term incorporates both the prestructuring of the potential meaning by the text and the reader's actualization of this 
potential through the reading process' (Iser 1974: xii). Volgens Holub (1984: 85) kan dit ook ' $n$ 'fenomenologiese leser' genoem word, dit wil sê 'n leser wat beskik oor al die voorwaardes om die literêre werk sy effek te laat hê, wat terselfdertyd 'n empiriese basis uitsluit. Deurdat die implisiete leser sowel 'n tekstuele konstruksie (Textstruktur) as 'n gestruktureerde handeling (Aktstruktur) is, is dit vir Iser moontlik om heen en weer tussen die teks en die leser te beweeg sonder om die bydrae van enige van die twee pole volledig uit te spel (Lategan 1985: 9). Die implisiete leser is dus ' $n$ middel waardeur die werklike leser betrek word deurdat dit aan hom 'n rol aanbied wat hy kan speel of ' $n$ houding wat hy kan inneem.

By wyse van ' $n$ kort ekskurs meen ek dit is belangrik om op hierdie stadium daarop te wys dat Iser se implisiete leser maar een van 'n hele reeks van 'lesers' is wat onderskei word. Lategan (1985: 5-8) stel 'n hele katalogus van lesers uit resente teorieë saam. Baie van hierdie lesers is identies of oorvleuel grootliks. As voorlopige klassifikasie onderskei Lategan drie groepe lesers, naamlik intratekstuele lesers (soos byvoorbeeld die mock reader, die geadresseerde, die implisiete of geïmpliseerde leser, die modelleser, die passiewe leser en die geënkodeerde leser), buite-tekstuele lesers (soos byvoorbeeld die oorspronklike leser, die lesers van die verlede wat die geskiedenis van die resepsie van die teks konstitueer, die saamgestelde leser, die naïewe leser of 'die man in die straat', die kritikus, die ingeligte leser, die super leser en die ideale leser) en in die derde kategorie lesers wat nòg intratekstueel nòg ekstratekstueel is (byvoorbeeld 'n sekere opvatting oor die ingeligte leser, die implisiete leser en die nie-outoritêre leser). Holub (1984: 153) meen dat hierdie oënskynlik eindelose stroom van meer en meer geraffineerde leserskonsepte verenig word deur, ten spyte van onderlinge verskille, 'their function as a lightning rod with respect to the "work itself".' Die doel van die identifisering van verskillende soorte lesers is om 'n mens te help om die leesproses self beter te verstaan. Die groot aantal lesers is ' $n$ bevestiging van die gekompliseerdheid van hierdie proses.

Dit gaan egter nou oor die siening van spesifiek Iser, en daarom word daar nie verder op al hierdie soorte lesers ingegaan nie.

\subsubsection{Repertoire}

'n Verdere baie belangrike begrip wat Iser hanteer, is die repertoire. Dit is die gemeenskaplike terrein waarop die teks en die leser ontmoet 
om kommunikasie te bewerkstellig. Dit kan in die vorm wees van verwysings na vroeëre werke, of na sosiale en historiese norme of na die totale kultuur waaruit die teks voortgekom het (Iser 1978: 69). Die repertoire se funksie is om deur die hervorming van die bekende elemente 'n agtergrond te vorm vir die proses van kommunikasie en tweedens 'n algemene raamwerk te voorsien waarin die boodskap of die betekenis van die teks georganiseer kan word (1978: 81). Die repertoire sluit hoofsaaklik die elemente in wat tradisioneel as die 'inhoud' van die teks beskou is (Holub 1984: 88).

\subsubsection{Strategie}

Strategie is die vorm of struktuur hoe die repertoire aangebied word. Strategie omvat sowel die ordening van die materiaal as die voorwaardes waaronder die materiaal gekommunikeer word. Soos Iser (1978: 86) dit stel: Sowel die immanente struktuur van die teks as die begripshandelinge wat daardeur in die leser ontlok word. Die funksies van strategieë is om die bekende te vervreem of te de-outomatiseer.

\subsubsection{Funksies van strategieë}

Onder funksies van teksstrategieë onderskei Iser twee beheersende strukture, naamlik dié van vooropstel en agteropstel en tema en horison. Eersgenoemde bewerk spanning in die teks wat uitloop op die vorming van die estetiese objek (Iser 1978: 95). Tema en horison behels die seleksie wat vanuit 'n meerderheid perspektiewe in 'n teks gemaak is. Die moontlike perspektiewe is dié van (1) verteller, (2) karakters, (3) plot en (4) dié wat vir die leser gemerk is (Iser 1978: 96). Wanneer die leser met enige van hierdie perspektiewe besig gehou word, word sy houding daarteenoor bepaal deur die horison waarmee hy daarna kykdie horison wat hy opgebou het deur wat hy vroeër gelees het en deur die ander perspektiewe. Hierdie perspektiewe werk vormend in op die leser se persepsie en dit beperk die aantal moontlike alternatiewe sodat die leser tot ' $n$ keuse gedwing word. Die verskillende toepassings van tema-en-horisonrangskikkings verteenwoordig die teksstrategieë wat die leser se persepsie van die elemente in die repertoire rig, en wat die produksie van 'n gepaste estetiese objek moontlik maak (Holub 1984: 89). 


\subsubsection{Die leesproses}

Om die leesproses fenomenologies te kan beskryf, is die idee van die "verskuiwende gesigspunt" belangrik. Dit is die manier waarop die leser se teenwoordigheid in die teks beskryf word (Iser 1978: 118). Die beweging van die verskuiwende gesigspunt word die 'dialectic of protension and retension' genoem (kyk Holub 1984: 90). Hierdie terme verwys na die aangepaste verwagtings en die getransformeerde herinnerings wat die leesproses kenmerk. Die leesproses kan as 'n proses van 'consistency building' gesien word. In die besigwees met die verskeidenheid van tekens of elemente van die teks, probeer die leser verbindings tussen hulle lê en 'n samehangendheid kry. In die proses vorm die leser Gestalten. Wanneer daar ' $n$ teken is wat bots met die tot-op-daardiestadium-gevormde Gestalt, sal die leser probeer om deur 'n proses van hersiening die sake weer samehangend te maak. Die dialektiek tussen die maak en die breek van illusies en die verwante ossilasie tussen betrokkenheid en waarneming is grondliggend vir die totstandkoming van die estetiese objek. Verder is dit ook hierdie proses wat verantwoordelik daarvoor is dat die teks as 'n 'lewende gebeurtenis' ervaar word (Iser 1978: 127-128).

'n Tweede aspek van leesproses wat Iser (1978: $135 \mathrm{vv}$ ) beklemtoon, is die beeldvormende aktiwiteit van die leser. Wanneer ' $n$ mens lees, is jy voortdurend besig om onbewustelik beelde te konstrueer. Beelde is egter nie dieselfde as persepsies nie. Wahrnemung (persepsie) vind slegs plaas wanneer 'n objek teenwoordig is om waargeneem te word, terwyl Vorstellung die afwesigheid of 'non-existence' van 'n objek veronderstel. Vorstellung is 'n noodsaaklike aspek van die kreatiewe verbeelding wat uiteindelik die estetiese objek produseer.

Uiteindelik definieer Iser (1974: 277) die leeshandeling soos volg: 'The activity of reading can be characterized as a sort of kaleidoscope of perspectives, pretensions, recollections.'

Suleiman (1980: 22-23) gee 'n baie nuttige omskrywing van Iser se definisie van lees:

The act of reading is defined as essentially a sense-making activity, consisting of the complementary activities of selection and organization, anticipation and retrospection, the formulation and modification of expectations in the course of the reading process. 


\subsubsection{Die interaksie tussen teks en leser}

Wat beskrywing van die interaksie tussen teks en leser bemoeilik, is die feit wat Iser (1978: 163-170) die assimmetrie tussen teks en leser noem: Die feit dat (1) die leser nie in staat is om te toets of sy verstaan van die teks korrek is nie en (2) die feit dat daar geen regulerende konteks tussen teks en leser bestaan nie. (Hierdie konteks moet deur die leser gekonstrueer word uit die tekstuele suggesties en tekens.)

Iser (1980: 106-119) se breedvoerige uiteensetting van hoe die interaksie tussen teks en leser verloop, kan skematies soos volg weergegee word:

Teks > Oop plekke (blanks) in die teks $>$ word ingevul deur die leser $>$ referensiële veld ontstaan $>$ word ingevul deur die tema-en-horisonstruktuur $>$ Leë plekke (vacancies) ontstaan $>$ dit word ingevul deur leser se horison $>$ onderlinge transformasies vind plaas $>$ dit lei uiteindelik tot die vorming van die estetiese objek.

\subsubsection{Gapings}

Die wyse waarop die teks die leser lei en kontroleer, is deur die funksionering van die gapings (Leerstellen) in die teks. Hierdie begrip kan nie presies gedefinieer word nie. Iser (1978: 170) praat (in navolging van Ingarden) daarvan as ' $n$ 'spot of indeterminacy' of as die 'no-man's land of indeterminacy' tussen geskematiseerde gegewes (Ansichten). Holub (1984: 93) wys daarop dat Iser doelbewus nie die begrip Unbestimmtheit wat hy hanteer, in besonderhede wil definieer nie, want daardeur sal die status daarvan as ' $n$ algemene begrip vir kommunikasie uitgeskakel word.

Iser onderskei verder tussen 'oop plek' en 'leë plek' en 'negasie':

\section{Oop plekke en leë plekke}

'Oop plek' verwys na die 'suspended connectability' in die teks terwyl 'leë plek' verwys na die 'non-thematic segments within the referential field of the wandering viewpoint' (Iser 1978: 198). Die oop plekke en leë plekke is die kaart vir die lees van die teks. Deur hulle struktuur en verskuiwende posisies rig die 'oop plekke' en die 'leë plekke' die leser se deelname aan die leesproses. Terselfdertyd lok hulle die leser uit om die struktuur te voltooi en om daardeur die estetiese objek te produseer.

2. Negasie

Sowel 'oop plekke' as 'leë plekke' kom voor op die sintagmatiese as 
in die sin dat dit die pad 'in die teks' uitlê. Op die paradigmatiese as is daar ' $n$ ander vorm van 'oop plek' wat Iser (1978: 212-213) negasie noem. In die leesproses word die leser dikwels bewus van die norme van die sosiale sisteem waarin hy leef. Die meeste moderne literatuur het die funksie om hierdie norme te bevraagteken. Om die gapings op die sintagmatiese vlak te kan invul, het die leser ' $n$ perspektief nodig waarvolgens vroeëre aanvaarde norme ongeldig is. Wanneer dit gebeur, het 'n negasie plaasgevind en is ' $n$ 'dynamic blank on the paradigmatic axis of the reading process' geproduseer. 'Negasies' en 'gapings' is die basiese middele waardeur kommunikasie plaasvind.

\subsection{Kritiek teen Iser}

Volgens Holub (1984: 100) is Iser se implied reader uiteindelik steeds 'n immanente konstruksie. Aan die een kant het hy' $n$ model wat berus op tekstuele kwaliteite soos 'oop plekke' en 'leë plekke' en aan die ander kant is daar die reaksie van die leser wat die produk van 'n abstrakte handeling is - dit terwyl Iser tog werk met die 'historiese leser'.

Holub (1984: 101) meen verder dat die groot kritiekpunt egter die kwessie van 'determinacy' en 'indeterminacy' in Iser se benadering is. Iser probeer 'n middelposisie tussen objektivisme en subjektivisme inneem deur te beweer dat die teks verskillende betekenisse toelaat maar tog terselfdertyd die moontlikhede beperk. Die leser is oënskynlik vry om die teks op verskillende maniere te konkretiseer of om verskillende betekenisse te skep. Tog meen Holub dat dit voorkom dat Iser op verskeie plekke hierdie vryheid weer terugneem en dat die leser nie kan interpreteer sonder dat hy onderwerp is aan die kriterium van 'n enkele bepalende element wat in die teks 'aanwesig' is nie. Op ' $n$ sekere punt is daar dus 'vastighede' in die teks aanwesig, ongeag van die leser se ken daarvan.

Iser werk dus met die idee dat die bepaaldhede en die onbepaaldhede van mekaar geskei kan word. Dit is egter slegs moontlik as 'n mens iets soos 'n 'suiwer teks' kan kry, dit wil sê iets wat op 'n onbemiddelde manier waargeneem kan word. Dít is egter nie moontlik nie. Daar is nie so iets soos 'innocent reading' nie (Culler 1980: 116). As leser bring 'n mens noodwendig eksterne informasie met jou mee en hierdie informasie speel 'n groot rol in die wyse waarop die teks omskep word in 'n ervaring met ' $n$ ' samehang en betekenis wat bevredig (Holland 1980: 123). 
Volgens sekere reader-response critics bestaan daar nie vóór die interpretasiehandeling reeds 'iets' out there nie. Die interpretasiehandeling produseer die verskynsels wat geïnterpreteer word. Wat ons sien en verstaan, is al reeds bepaal deur 'n voorafgaande perspektief of raamwerk wat ons sien en verstaan moontlik maak. Iser hou nie genoegsaam daarmee rekening dat die interpreteerder alreeds binne ' $n$ konvensie of onder'n stel voorwaardes opereer nie.

Bogenoemde kritiek is veral afkomstig vanaf Stanley Fish (kyk Holub 1984: 102). Fish se eie standpunt oor 'determinacy' kom op die volgende neer:

The form of a reader's experience, formal units, and the structure of intention are one, that they come into view simultaneously, and that therefore the questions of priority and interdependence do not arise. What does arise is another question: what produces them? That is, if intention, form, and the shape of the reader's experience are simply different ways of referring to (different perspectives on) the same interpretive act, what is that act an interpretation of? I cannot answer that question, but neither, I would claim, can anyone else, although formalists answer it by pointing to patterns and claiming that they are available independently of (prior to) interpretation (Fish 1980: 177).

Volgens Fish soek die Formaliste hierdie patrone byvoorbeeld in statistiese gegewens, soos byvoorbeeld die getal tweelettergrepige woorde per honderd woorde of in grammatikale 'feite'. Hy antwoord hierop soos volg: 'Whatever they (= die patrone waarmee die Formaliste werk - JB) are I would argue that they do not lie innocently in the world but are themselves constituted by an interpretive act, even if, as is often the case, that act is unacknowledged' (1980: 177). Hy voer sy argument verder deur aan te toon dat nòg reëleindes nòg alliterasie nòg die 'feite' van die grammatika onafhanklik en vóór die interpretasiehandeling reeds bestaan. Al hierdie sake sowel as die betekenis wat daaraan toegeken word, is die gevolg van konvensie. Betekenis is dus in die 'interpretive community' geleë.

Fish eindig sy argument op hierdie punt met die volgende stelling: 'The moral is clear: the choice is never between objectivity and interpretation, but between an interpretation that is unacknowledged as such and an interpretation that is at least aware of itself' (1980: 178).

Die konsekwensies van hierdie argument nog verder deurgetrek, bring ' $n$ mens by Post-strukturalisme. Terwyl die resepsieteoretici die 
fokus verskuif het vanaf die teks na die leser, het die Post-strukturaliste alle fokus geplaas op die tekstualisering van die leser. Die leser is dus nie meer 'n verenigde sentrum vanwaar betekenis en interpretasie hulle oorsprong het nie, maar eerder 'n konstruksie wat gekenmerk word deur verskeidenheid en geskeidenheid. Soos Barthes (1974: 10) dit stel: "This "I" which approaches the text is already itself a plurality of other texts, of codes which are infinite or, more precisely, lost (whose origin is lost).' Waar die resepsieteoretici dus die fokus verskuif het vanaf die teks na die leser, het die Post-strukturaliste alle fokus op die teks na die agtergrond geskuif deur die leser te tekstualiseer (Holub 1984: 154).

Hoewel daar dus ernstige kritiek teen fasette van Iser se benadering uitgespreek is, is sy model tog baie nuttig. Dit gee ' $n$ terminologiesisteem wat kan dien as wyse vir toegang tot werklike tekste. Sy sisteem help om die kompleksiteite van die leesproses duideliker onder oë te sien. Tekste is gekonstrueer met die oog daarop dat dit gelees moet word en tekste dikteer die voorwaardes vir hulle leesbaarheid (Holub 1984: 106). Veral omdat sy model baie maak van die Wirkung van die teks (onder meer deur die taalhandelingsteorie te betrek), hou dit vrugbare toepassingsmoontlikhede vir die interpretasie van NuweTestamentiese tekste in. Dit moet egter omsigtig (en moontlik met aanpassings) gedoen word.

\section{EMPIRIESE RESEPSIE-ONDERSOEKE}

\subsection{Algemene tipering}

Kritiek teen Jauss en Iser se werk wat telkens na vore kom, is dat hulle nie 'n sosiologiese begronding van die leser gee nie (Holub 1984: 135). Binne die raamwerk van die empiriese literatuurstudie is daar geoordeel dat hierdie leemte ondervang kan word deur analises van die 'werklike' leser te makk. Empiriese ondersoeke moet ontwerp en uitgevoer word om praktiese resultate in sosiale kontekste te lewer (kyk Schmidt 1981: 317). Indien dit gedoen word, kan die abstrakte begrippe 'implisiete leser' en 'verwagtingshorison' vermy word. Uit die staanspoor is dit dus duidelik dat die empiriese resepsiestudies in kompetisie met die hermeneutiese teorieë is. Die empiriese studies maak aanspraak op geldigheid vir hulle resultate wat na hulle oordeel by die hemeneutiese studies ontbreek. Empiriese resepsie-ondersoeke 
wil literêre navorsing doen deur gebruik te maak van metodes wat reeds bekend en beproef in die sosiale en natuurwetenskappe is. Hier geld eise soos intersubjektiwiteit en gekontroleerde en kontroleerbare toepassings van eksplisiete teorieë, soos dit deur die konsensus van 'n groep navorsers bepaal is (Ohlhoff 1986: 61).

Holub (1984: 140) gee ter illustrasie van hierdie metode die volgende voorbeeld:

Sewentien gedigte uit verskillende periodes die afgelope 250 jaar is uitgekies en sewentien matriekleerlinge is as proefkonyne gebruik. Die leerlinge is gevra om in volgorde elke teken (dit wil sê elke letter en punktuasieteken) in die eerste ses tot nege reëls van elke gedig te raai. Nadat die stadigste leerling sy raaiskoot neergeskryf het, is die regte antwoord op die bord gegee en moes die leerlinge voortgaan om die volgende teken te raai. Die resultaat van die ondersoek het getoon dat die klassieke gedigte $61 \%$ reg voorspel is en die moderne gedigte $53 \%$. Hieruit is die gevolgtrekking gemaak dat wat die resepsie deur die leser betref, moderne poësie minder kommunikeerbaar is as klassieke poësie.

\subsection{Kritiek teen empiriese resepsie-ondersoeke:}

Die oorgrote meerderheid van vrae wat werklik saak maak in literêre studies, kan nie deur empiriese metodes beantwoord word nie, of as hulle dan 'bewys' kan word, sou dit reeds deur die oplettende student raakgesien gewees het sonder die statistiese gegewens (Holub 1984: 141).

Tog kan die studie van die werklike lesings van 'n gegewe teks nuttig wees om die werking van die teks en die sosiologie van die leser te ondersoek. In die geval van die resepsie van die Bybel kan waardevolle resepsie-ondersoeke vanuit hierdie benadering gedoen word, veral gesien in die lig van soveel wyduiteenlopende resepsies van die Bybel in verskillende godsdienstige en sosiaal-politiese groepe. Dit kan moontlik dien daartoe dat verskille noukeurig omskryf kan word, wat weer as ' $n$ basis vir gesprek tussen groepe kan dien.

\section{8. 'N VERKENNING VAN DIE MOONTLIKHEDE VAN 'N RESEPSIETEORETIESE BENADERING TOT DIE LEES VAN ROMEINE 7:7-25}

Soos dit uit die teoretiese uiteensetting hierbo geblyk het, is daar drie 
moontlikhede wat in ' $n$ resepsieteoretiese benadering tot ' $n$ teks gevolg kan word.

- Daar kan probeer word om te bepaal hoe werklike lesers met verloop van tyd op die bepaalde werk gereageer het. Hier moet by voorkeur aandag gegee word aan resepsiedokumente, soos byvoorbeeld preke, kommentare, kantaantekeninge, wetenskaplike artikels (Jauss se benadering).

- Daar kan gevra word hoe en in watter mate die teks die reaksies van lesers kan rig. Die teks self kan met die oog hierop ondersoek word (Iser se benadering).

- Empiriese of eksperimentele ondersoeke na die reaksies van tydgenootlike lesers kan uitgevoer word.

Vervolgens word daar in hierdie volgorde enkele verkennende opmerkings gemaak oor die resepsie van Romeine 7:14-25.

\subsection{Resepsiegeskiedenis}

Dat die leser as verwerkende subjek 'n wesenlike aandeel het in die resepsie van 'n bepaalde teks, blyk duidelik uit die geskiedenis van die resepsie van hierdie teks. Telkens het die sake wat die lesers van buite die teks met hulle saamgebring het, 'n wesenlike invloed op hulle resepsie uitgeoefen. Ter illustrasie van die geldigheid van hierdie stelling, word slegs 'n paar van die hoofmomente uit die resepsiegeskiedenis van hierdie bepaalde teks hier aangestip.

\subsubsection{Die Pelagiaanse stryd}

Gedurende die eerste drie eeue van die Christelike jaartelling is Romeine 7:14-15 gelees as 'n beskrywing van die onbekeerde mens, dit wil sê die heiden, die mens voordat hy 'n Christen geword het. Ook Augustinus het aanvanklik die teks verstaan as beskrywing van die situasie van die sondaar ante gratiam. In sy stryd teen Pelagius verander hy egter van mening (vgl Noordmans 1949: 59; Wilckens 1980: 105). Pelagius het die gedagte verwerp dat daar ' $n$ erfsonde bestaan wat alle mense by wyse van voortplanting van Adam geërf het. Hy meen dat, ten spyte van Adam se val, ' $n$ sondelose lewe in beginsel moontlik is en dat elkeen wat dit ontken, ook die vrye wil en verantwoordelikheid van die mens ontken (kyk Schulze 1978: 126). 
Indien Romeine 7:14-25 gelees word as dat dit betrekking het op die toestand van die mens buite Christus, lyk dit inderdaad of hier regverdiging vir Pelagius se opvattings gevind kan word: Die mens is in beginsel goed, want die nómos tôu noós in hom is goed en in sy diepste wese wil hy graag God se wet gehoorsaam wees: sunēdomai gàr tō nómō tồ theoû katà tòn esō anthrōpon (vs 22, 23).

Dit is uit die geskiedenis goed bekend hoedat Augustinus hom teen Pelagius verset het en in watter intense stryd hulle gewikkel was (vgl Schulze 1978: 13-141). Augustinus het dus sy interpretasie van hierdie teks verander en verklaar dat ' $n$ interpretasie wat die teks op die situasie ante gratiam betrek, Pelagiaanse kettery is. In sy Retractiones vertel hy hoedat hy sy interpretasie van die teks gewysig het en hoe hy daartoe gekom het om die gedeelte op Paulus self te laat slaan. Dit sal waarskynlik nie reg aan Augustinus laat geskied as beweer word dat eksegetiese oorwegings géén rol in hierdie ommeswaai gespeel het nie. Wat egter bo alle redelike twyfel duidelik is, is dat die Pelagiaanse stryd 'n groot rol daarin gespeel het (Pelser 1984: 96; Wilckens 1980: 105).

Dit blyk dus dat 'n konkrete lewensituasie (die Pelagiaanse stryd) in hierdie geval 'n groot (beslissende?) invloed uitgeoefen het op die resepsie van die teks.

\subsubsection{Luther en die Reformatoriese belydenisskrifte}

Die latere interpretasie van Augustinus het 'n groot invloed uitgeoefen op die verwagtingshorison van Luther met betrekking tot die resepsie van hierdie teks, soos Wilckens (1980: 107) dit stel: 'In seiner (= Luther se - JB) Römer-Vorlesung von 1516 hat er sich bei der Auslegung von Röm 7,7ff eng an den späteren Augustinus angeslossen und übernimmt von ihm nahezu alle exegetischen Einzelurteile.' Luther voer twaalf gronde aan waarom hy meen dat Paulus met die 'ek' van Romeine 7 die 'geestelike mens' bedoel en waarom dit hoegenaamd nie op die mens sonder Christus, soos wat dit in die vroeëre dele van Romeine geskets is, van toepassing kan wees nie. Hierin is hy ook nagevolg deur Calvyn (kyk Michel 1978: 241). Die Lutherse (en in navolging van hom ook die Reformatoriese) grondbeskouing dat die Christengelowige simul iustus et peccator is, het sy deurslaggewendste bevestiging ook juis uit die spesifieke interpretasie van hierdie teks gekry (Pelser 1984: 92, 96).

In die Reformatoriese kerke is die Lutherse uitleg van die teks oorgeneem en is dit veral gebruik in die bestryding van die Roomse leer van 
die vrye wil (Wilckens 1980: 109). Hierdie interpretasie het neerslag gevind in die Reformatoriese belydenisskrifte. In die Westminster Confession of Faith (1647) staan daar dat die gelowige se 'beste werke' besmet is 'and mixed with so much weakness and imperfection that they cannot endure the severity of God's judgement' (Hoofstuk 16, paragraaf 6). Die teksverwysings wat hierby aangegee is, sluit Romeine 7:15, 18 in. Die Nederlandse Geloofsbelydenis (1561) sê met verwysing na die mense wat Jesus Christus as hulle enigste Saligmaker aangeneem het, dat dit nie wil sê dat 'daar nie nog groter swakheid in hulle is nie, maar hulle stry daarteen deur die Gees al die dae van hulle lewe ...' (Artikel 29). By die Franse teks van die woorde wat hier aangehaal is, word daar onder andere verwys na Romeine 7:6, 17. In vraag 114 (Sondag 44) vra die Heidelbergse Kategismus (1563) of mense wat tot God bekeer is, in staat is om die gebooie van God volkome te onderhou, en antwoord dan: 'Nee, want ook die allerheiligstes het maar 'n klein beginsel van hierdie gehoorsaamheid solank as hulle in hierdie lewe is (a); maar só, dat hulle met 'n ernstige voorneme nie alleen na sommige nie, maar na al die gebooie van God begin lewe (b).' By die (a)-gedeelte van die antwoord word daar onder meer verwys na Romeine 7:14, 15 en by die (b)-gedeelte na Romeine 7:22.

Hoewel Luther op 'n bepaalde punt van die latere Augustinus verskil (kyk Wilckens 1980: 107), is dit tog duidelik dat Augustinus se interpretasie ' $n$ groot invloed op Luther s'n uitgeoefen het. Hierdie tradisie was dus 'n belangrike buite-tekstuele gegewe wat meegespreek het in Luther se resepsie. ' $n$ Ander buite-tekstuele faktor wat ' $n$ invloed uitgeoefen het, is die stryd teen Rome se leer van die vrye wil.

Dit is interessant om daarop te wys hoedat ook die teenoorgestelde interpretasie in die sewentiende eeu steeds ' $n$ aanhang geniet het, weer eens as gevolg van 'n dogmatiese stryd. So skryf Hugo de Groot in sy Annotationes: 'God zij geprezen, dat de beste christenen, en dat zijn die der eerste drie eeuwen, deze plaats so hebben begrijpen als't behoort' (aangehaal deur Noordmans 1949: 60). By die Arminiane was daar dus 'n duidelike terugkeer na die heel vroegste interpretasie waarvolgens hierdie teks gelees is as verwysend na die onbekeerde mens.

\subsubsection{Piëtisme en verdere geskiedenis}

Die benadering van die Reformatoriese kerk dat sonde ' $n$ wesenskenmerk van die Christen in hierdie lewe bly, was vir die vroomheidpraktyk van die sewentiende-eeuse Piëtisme onaanvaarbaar (Wilckens 
1980: 110). Hulle het die gevaar in hierdie leer daarin gesien dat enersyds aan die gegewenheid van die sonde heimlik legitimiteit verleen word, en andersyds dat die heilservaring abstrak bly en nie 'n werklikheid word wat die Christelike lewe positief bepaal nie. Daarom is die tradisionele Lutherse verklaring so aangepas dat Romeine 7 gesien word as slegs van toepassing op die Christen in sy nog-nie-bekeerde staat. As bekeerde het die Christen finaal en in die konkrete alledaagse lewe met die sonde afgereken. Hierdie interpretasie geniet vandag nog wye aanvaarding in godsdienstige herlewingsbewegings en pinkstergroepe (Pelser 1984: 97).

Dunn (1975: 257) wys daarop dat die 'ek' van Romeine 7, onder invloed van die Piëtisme, spesifiek van toepassing gemaak is op Paulus se persoonlike ervaring voordat hy 'n Christen geword het. Daarvolgens word Romeine 7:14-25 gesien as Paulus se outobiografiese weergawe van sy eie lewenservaring voordat hy 'n Christen geword het.

Dit is hieruit weer eens duidelik hoedat teks-eksterne faktore (die Piëtistiese vroomheidsmodel) 'n deurslaggewende rol gespeel het in die resepsie van Romeine 7 op ' $n$ bepaalde stadium in die geskiedenis.

'n Mens sou die pad ook verder kon loop en wys hoedat die filosofie van Immanuel Kant in die agtiende eeu, die Duitse idealisme in die negentiende eeu en die dialektiese teologie in die twintigste eeu, telkens weer opnuut ' $n$ beslissende wending in die resepsie van hierdie teks meegebring het (kyk daarvoor Wilckens 1980: 111-117). Gesien in die lig van die doel van hierdie artikel, naamlik om enkele verkennende opmerkings oor die bruikbaarheid van 'n bepaalde raamwerk vir die lees van hierdie teks te maak, word verdere loop van die resepsiegeskiedenis nie hier uiteengesit nie.

'n Belangrike bydrae wat die resepsieteorie tot die teologiese hermeneutiek kan bied, is om verskille wat in die interpretasie van tekste voorkom, te verklaar. So byvoorbeeld gee Suleiman (1980: 36) die volgende verklaring waarom die verstaan van 'n teks voortdurend wissel: 'These changes in understanding are always functions of changes in the reader's horizon of expectations, changes which are themselves the result of both literary evolution and the evolution of cultural, political and social conditions and norms in the society at large.' Dit is ongetwyfeld 'n verhelderende opmerking ten opsigte van die resepsiegeskiedenis van Romeine 7. 


\subsubsection{Sinopsis van interpretasieverskille}

By wyse van samevatting kan gesê word dat Romeine 7:7-25 die volgende resepsies deur die loop van die geskiedenis gehad het (vgl Newman 1983: 126-133 en Dunn 1975: 258-264):

- Outobiografiese interpretasie: Dit gaan oor die ervaring van Paulus self.

Hieronder volg 'n verdere verdeling:

(a) Dit gaan oor Paulus se verlede, sy ervaring voordat hy Christen geword het;

(b) Dit gaan oor Paulus se hede, sy ervaring as Christen.

- Universele interpretasie: Dit is refleksie op die ervaring van die mens.

Met hierdie belangrike verdere verdeling:

(a) Die 'ek' sluit ander mense in, in die betekenis van 'ons as Christene';

(b) Die 'ek' sluit ander mense in, in die betekenis van 'ons as mense' in ons voor-Christelike staat.

- Retoriese of onpersoonlike interpretasie: Die 'ek' in hierdie teks word analoog aan die 'ek' in 1 Korintiërs 13 gebruik. Dit is stilistiese tegniek waarmee Paulus lewendigheid aan sy argument wou verleen en assosiasie met sy leser wou skep.

Pelser (1984: 99) maak die interessante opmerking dat dit in die geskiedenis geblyk het dat dogmatici meer geneig is om $2 a$ te kies en eksegete om $2 b$ te kies. Of ' $n$ mens dogmatikus of eksegeet is, is ' $n$ buitetekstuele gegewe, iets wat jy met jou 'saambring' wanneer jy die teks interpreteer. Die feit dat daar 'n patroon waarneembaar is in die keuses wat deur hierdie twee groepe uitgeoefen word, bevestig weer eens die saak wat hierbo al gestel is: Dit wat die interpreteerder van buite die teks met hom saambring (sy verwagtingshorison), beïnvloed die interpretasie grootliks.

\subsubsection{Moet daar 'n keuse gemaak word?}

Afhangende vir watter doel 'n mens jouself met hierdie teks besig hou, is dit wel in sekere gevalle nodig om 'n keuse te maak. So byvoorbeeld hou Newman (1983: 124) hom besig met die vraag hoe hierdie gedeelte vertaal moet word. Die interpretasies is so uiteenlopend, dat dit nie met een vertaling weergegee kan word nie. In hierdie geval is dit dus nodig om 'n keuse te maak. 
Een van die belangrike uitvloeisels van ' $n$ resepsieteoretiese benadering tot tekste is dat daar weggekom is van die idee van 'die outeur het net een ding bedoel en daarom kan die teks net een ding beteken'. Deur aandag te skenk aan die rol van die leser is daar ingesien dat daar inderdaad iets soos meerdere geldige interpretasies van dieselfde teks kan wees (kyk Combrink 1984: 35). Die verskille in interpretasies van dieselfde teks, word deur resepsieteoretici juis toegeskryf aan die rol wat die leser in die leesproses speel: 'To understand interpretive disagreements, to understand the ambiguity or openness of literary meaning, one must study the reading process. No other area of literary criticism offers such an interesting and valuable program' (Culler 1980: 66). Todorov (1980: 72) stel dit egter nog duideliker: 'Two accounts of the same text will never be identical. How do we explain these diversity? By the fact that these accounts describe, not the universe of the book itself, but this universe as it is transformed by the psyche of each individual reader.'

Hiermee word nie beweer dat interpretasie ' $n$ willekeurige proses is waarin alle interpretasies van ' $n$ teks op dieselfde mate van geldigheid kan aanspraak maak nie. Die grense wat die teks stel kan nie willekeurig oorskry word nie. Tog blyk dit dat daar juis binne die grense van die teks, meer as een geldige interpretasie kan wees. Dit beteken dat die teks as knooppunt van die verstaansgebeure steeds die primêre plek in die wetenskaplike ondersoek moet inneem. Die teks is leesbaar omdat dit sekere wette en strukture gehoorsaam. Hiermee word nie die sigbare strukture op die teksoppervlakte bedoel nie, maar die onderliggende strukture wat die teks bymekaar hou. Hierdie strukture maak dit moontlik dat die teks gelees kan word, maar terselfdertyd beperk dit die lesing daarvan. Om te lees is om nuwe lewe aan 'n teks te gee, terwyl die teks gerespekteer word. ' $n$ Teks is dus oop in die sin dat dit altyd nuwe lesings ontlok - soos duidelik uit die resepsiegeskiedenis van Romeine 7 blyk.

Die probleem van die uiteenlopende interpretasies van Romeine 7:7-25 is dus vanuit hierdie agtergrond te verklaar. ' $n$ Mens sou kon redeneer daaroor of die begeerte om ' $\mathrm{n}$ keuse te maak tussen 'regte' of 'verkeerde' interpretasies van hierdie teks nie juis deur die aard van kommunikasie deur middel van 'n geskrewe teks, minder akuut gemaak word nie. Dit hef egter nie die teoloog se verantwoordelikheid op om die teks steeds intensief te ondersoek nie. Hoewel die presiese vasstelling van die grense van die teks (wat vir alle mense van alle tye geldend is) nie haalbaar is nie, kan dit tog met verloop van tyd blyk dat een of meer van die interpretasies die tekstuele grense oorskry. 


\subsubsection{Die waarde van Jauss se model ten opsigte van die resepsie van Romeine 7:14-25.}

Met hierdie oorsig oor ' $n$ paar hoofmomente in die resepsiegeskiedenis van hierdie teks, is die geldigheid van Jauss se opvattings soos hierbo (4.2) uiteengesit, myns insiens duidelik geillustreer. Soos wat die verwagtingshorisonne van die lesers deur die geskiedenis heen voortdurend verander het, so het die resepsie van die teks telkens verander. Die basiese uitgangspunt van die resepsieteorie, dat die leser skeppend betrokke is by die leesaktiwiteit en dat teks-eksterne faktore noodwendig meespreek in die resepsie van 'n teks, word ook deur hierdie oorsig bevestig. In die teoretiese oorsig oor Jauss se benadering hierbo (4.3) is reeds gewys op die waarde van die beskrywing van die resepsiegeskiedenis van ' $n$ bepaalde teks. Dit het 'n belangrike plek om in die teologiese hermeneutiek in te neem.

\subsection{Lesersaanduidings in die teks van Romeine 7:7-25}

Die tweede moontlikheid wat in 'n resepsieteoretiese benadering tot ' $n$ teks gevolg kan word, is om te probeer vasstel in watter mate die teks self die reaksies van die lesers (kan) rig. Dit behels ' $n$ intensiewe ondersoek van alle aspekte van die teks self. Uiteraard is dit nie moontlik binne die opset van hierdie artikel nie, en daarom volg ook hier slegs enkele verkennende opmerkings.

\subsection{1 'Die leser' in Romeine 7:7-25}

Wuellner (1985: 3) wys daarop dat ons so gewoond daaraan is om aan Paulus se lesers in historiese, sosiologiese en natuurlik, teologiese terme te dink, dat ' $n$ mens waarskynlik dadelik in daardie terme sal begin dink as daar gepraat word van 'n tipologie van lesers in die briewe van Paulus. Tog gaan die begrip heelwat verder, en moet daar in die definisie van 'die leser/gehoor' van Paulus se briewe onderskei word tussen twee tipes lesers, naamlik (1) die empiriese leser - dit kan die historiese Romeine wees of die reële lesers in enige ander tyd, en (2) die implisiete leser - dit is die leser wat deur die skrywer in die teks geskep word en wat die rol vervul van dit wat die outeur van sy lesers verwag. Op hierdie basis onderskei Wuellner tussen persuasion vir diskoers wat gerig is op empiriese lesers en conviction vir diskoers wat gerig is op fiktiewe lesers. 
Ten einde die 'convincing character' van Romeine te kan vasstel, is dit nodig om meer te weet van die soort leser vir wie die argumente 'n normatiewe rol speel. Hier onderskei Wuellner (1985: 4) tussen drie tipes implisiete lesers:

- Die universele leser - wanneer Paulus eksplisiet of implisiet alle gelowiges of die kerk as geheel aanspreek, of wanneer hy verwys na die consensus omnium. Hierdie soort leser word aangespreek in tekste wat van die derde persoon enkelvoud of meervoud gebruik maak, maar dikwels ook in tekste met 'ons' as referent (byvoorbeeld 1 Korintiërs 14:1-25).

- Die individuele leser of 'single interlocutor' - dit is die leser wat aangespreek word wanneer daar van die diatribe-styl gebruik gemaak word waarin ' $n$ 'jy' of 'julle' in vraag-en-antwoordvorm aangespreek word (byvoorbeeld 1 Korintiërs 15).

- Die skrywer in gesprek met homself - in hierdie geval word niemand aangespreek nie, behalwe die skrywer wat met homself kommunikeer. Daar is gedeeltes in 1 Korintiërs waar Paulus persoonlike emosies uitspreek deur byvoorbeeld 'n eerste-persoon-uitroep of in retoriese vrae wat as uitroepe funksioneer.

Uit hierdie bespreking kan 'n mens sien watter nuttige apparaat hierdie onderskeidings bied vir beskrywing van die probleem van Romeine 7:7-25. Dit lyk of sowel die eerste as die derde soort implisiete leser in hierdie teks geïdentifiseer kan word. Hoewel daar nie van die eerste persoon meervoud in hierdie teks gebruik gemaak word nie, is daar genoegsame aanduidings in die interteks van Paulus dat hy ook die eerste persoon enkelvoud 'ek' gebruik in gevalle waar hy 'n universele gehoor in gedagte het (byvoorbeeld Gal 2:18-21). Die uitroep van vers 24 asook die klaarblyklike sterk emosie wat uit die beskrywing van die innerlike stryd van die 'ek' blyk, is weer tipies aanduidings van die derde soort implisiete leser. Dit is moontlik dat die teks hierdie ambivalensie handhaaf en dit as kommunikasiestrategie uitbuit.

\subsection{2 'Oop plekke'}

Iser se konsep van Leerstellen is baie spesifiek met die oog op narratiewe teks, waar daar byvoorbeeld sprake is van oop plekke wat geskep word deur die wisseling in perspektiewe van verteller, karakters en plot, ontwerp. Of dit direk net so oorgeneem kan word op briefliteratuur is nie sonder meer duidelik nie. 'n Deeglike beskrywing van die 
genrekonvensies en tekseienskappe van die Nuwe-Testamentiese briefliteratuur behoort hierop lig te kan werp.

Hoewel dus nie sonder meer in spesifiek Iser se terme nie, kan 'n mens tog sekerlik praat van 'oop plekke' in hierdie teks, dit wil sê dinge wat nie presies bepaal is nie, en wat deur die leser ingevul moet word. So sou ' $n$ mens byvoorbeeld van die referent van die 'ek' in Romeine 7 as ' $n$ 'oop plek' in die teks kon praat. Dit is verder ook nie sonder meer duidelik wat met nómos en toîs mélesin en met nómos tồ noós bedoel word nie. Dit is interessant om te sien hoedat hierdie 'oop plekke' in die resepsiegeskiedenis van hierdie teks ingevul is. Baie het dit as basis gebruik vir die konstruksie van 'n 'Pauliniese antropologie' of 'Pauliniese psigologie' (kyk onder andere Noordmans 1949: 68 vv en Dunn 1975: $256 \mathrm{vv})$.

\subsubsection{Teksstrategieë}

Die teks bevat heel besondere strategieë waarvolgens die repertoire aangebied word. So byvoorbeeld is daar ' $n$ retoriese vraag in vers 7 ( $t \bar{i}$ oûn eroûmen; ho nómos hamartía); daar is die gebruik van die eerste persoon enkelvoud, die praesenstyd by die meeste werkwoorde, daar is die dialektiese uitsprake in vers 19 en 20 (ou gàr ho thélō poiō agathon, allà ho ou thélō kakòn tôuto prassō ...), daar is die uitroep in vers 24 (talaipōros egō anthrōpos), daar is 'n groot aantal herhalings en samevattings in die gedagtelyn (vers $18-19$ herhaal wat in $14-15$ gesê is; 20 herhaal $17 ; 21-23$ is 'n samevatting van $14-20$ en 25 is 'n samevatting van die hele perikoop), en ' $n$ mens sou nog meer dinge kon identifiseer.

Die tema van die wet en sy plek en funksionering word behandel teen die horison van dit wat reeds in die eerste ses hoofstukke oor die wet gesê is. Baie van die sake wat hier geïdentifiseer is, is middele van vooropstelling en agteropstelling wat in die teks ingespan word om die leesproses te rig en wat die leser lei om 'n geldige en gepaste estetiese objek te skep. Hóé presies hierdie (en nog baie ander) strategieë in die lees van die teks funksioneer, word nie hier in besonderhede uitgewerk nie, aangesien dit verder sou gaan as die mikpunt van verkennende opmerkings wat as doel van hierdie artikel gestel is.

\subsubsection{Die verskuiwende gesigshoek}

Wanneer die leser by Romeine 7 kom, het hy alreeds ' $n$ bepaalde 
Gestalt gevorm in die lig van wat hy in hoofstukke 1 tot 6 gelees het. Die feit dat hierdie perikoop begin met die vraag of die wet dus nou sonde is, is ' $n$ duidelike aanduiding wat die leser uit die teks kry om nie 'n verkeerde beeld oor die wet na te hou op grond van wat in die direk voorafgaande gedeelte gesê is nie. Die moontlike verkeerde beeld wat die leser op hierdie stadium van die wet mag hê, word in hierdie perikoop deurbreek. Daarom dat Kümmel (kyk Newman 1983: 131) hierdie perikoop "n verdediging van die wet' noem. Juis deur die perikoop met die retoriese vraag in te lei, word die leser daarop attent gemaak dat hy sy beeld van die wet waarskynlik in die lig van wat nou volg, sal moet hersien, maar ook dat hy weer sal moet terugkyk na dit wat hy reeds oor die saak gelees het. Die verskuiwende gesigshoek van die leser word gelei om vanuit die perspektief van die implisiete outeur terug te kyk na wat hy reeds gelees het en dit te modifiseer: Dit is nie die wet wat sleg is nie, dit is die sonde wat die goeie wet vir sy eie doeleindes misbruik.

Hiermee is beslis nie naastenby alles gesê wat in hierdie verband gesê kan word nie.

\section{3 'n Empiriese ondersoek na die resepsie van die teks deur kontemporêre lesers}

Deur middel van vraelyste en onderhoude kan die resepsie van hierdie teks deur kontemporêre lesers vasgestel word. Resultate wat verkry is op grond van die vorige twee fases van die resepsieteoretiese ondersoek kan moontlik daardeur verder ondersteun word. So sou dit byvoorbeeld interessant wees om te sien of die neiging dat die teks deur dogmatici en eksegete oor die algemeen verskillend geïnterpreteer word, nog bestaan. Ook sou dit interessant wees om te sien hoe verskillende godsdienstige, filosofiese, politieke en kultureel-sosiale opvattings van vandag ' $n$ rol speel in die resepsie van die teks.

Sodanige ondersoek kan beslis waardevol wees, hoewel 'n mens nie al die aansprake van voorstanders van hierdie benadering hoef te deel nie.

\section{NET MAAR 'N NUWE MODE?}

Ons leef in 'n tyd wat wetenskaplike metodes redelik vinnig kom en gaan. Die beswaar kan uitgespreek word dat alles maar net verbygaande modes is en dat 'ander belangriker werk' agterweë kan bly. 
In die eerste plek sou 'n mens hierop moet toegee dat nie alle nuwe benaderings en metodes van ondersoek altyd ewe vrugbare resultate oplewer nie. Tog is dit deel van die voortdurende eksperimentele aard van die wetenskap. Deur telkens op nuwe maniere met die teks van die Nuwe Testament om te gaan, vind daar juis ' $n$ groei in kennis plaas, al mag dit dalk in die geval van ' $n$ bepaalde benadering net die kennis wees dat die metode nié vrugbare resultate oplewer nie.

Malan (1983: xiii) wys ook daarop dat 'n benadering wat besondere aandag aan die rol van die leser gee, die vrees kan laat ontstaan dat die sentrale objek van ondersoek van die literatuurwetenskap, naamlik die teks, nie meer in fokus sal wees nie, maar dat dit sal verskuif na sake buite die werk. Die vrees is egter in die literatuurwetenskap reeds as ongegrond bewys. Ook wat die Nuwe Testament betref, kan die klem op die rol van die leser by sommige die indruk laat dat die Bybel nou 'uit die standpunt van die leser' gelees moet word en dat die teks na die agtergrond sal verskuif. Soos hopelik uit hierdie artikel blyk, is dit 'n ongegronde vrees.

In baie opsigte is die manier van omgaan met 'n teks vanuit 'n resepsieteoretiese benadering nie noodwendig revolusionêr nuut nie. Indien dit moontlik die verwagting is wat deur hierdie artikel by die leser geskep is, moet hierdie verwagting nou deurbreek word! Tog meen ek dat die benadering genoegsame moontlikhede bied om intensief betrek te word in die wetenskaplike bestudering van die teks van die Nuwe Testament.

\section{Literatuurverwysings}

BARTHES, R 1974. S/Z. New York: Hill.

COMBRINK, HJB 1984. Multiple meaning and/or multiple interpretation of a text. Neotestamentica 18, 26-37.

COMBRINK, HJB [1986]. The changing scene of Biblical interpretation, in Petzer \& Hartin [1986].

CULLER, J 1980. Literary competence, in Tompkins 1980: 101-117.

CRONJE, J v W [1986]. Defamiliarization in the Letter to the Galatians, in Petzer \& Hartin [1986].

DU PLESSIS, JG 1985. Clarity and obscurity: A study in textual communication of the relation between sender, parable and receiver in the Synoptic Gospels. D Th - dissertation, University of Stellenbosch.

DUNN, JDG 1975. Rom 7, 14-25 in the Theology of Paul. Th Z 31, 257-273.

FISH, S 1980. Interpreting the Variorum, in Tompkins 1980: 164-184.

FOWLER, R 1983. Who is 'the reader' of Mark's Gospel? SBL Seminar Papers.

HOLLAND, NN 1980. Unity Identity Text Self, in Tompkins 1980: 118-133.

HOLUB, RC 1984. Reception theory: A critical introduction. London: Methuen.

ISER, $W$ 1974. The implied reader: Patterns of communication in prose fiction from Bunyan to 
Beckett. Baltimore: Johns Hopkins University Press.

ISER, W 1978. The act of reading: $A$ theory of aesthetic response. London: Routledge \& Kegan Paul.

ISER, $W$ 1980. Interaction between text and reader, in Suleiman \& Crosman 1980: $106-119$.

JAUSS, HR 1970. Literary history as a challenge to literary theory. New Literary History 2, 7-37.

LATEGAN, BC 1984. Current issues in the hermeneutical debate. Neotestamentica 18, $1-17$.

LATEGAN, BC 1985. Coming to grips with the reader - some guidelines for a discussion of reader-orientated approaches. (Unpublished paper read at a meeting of the SNTS seminar on the role of the reader.)

LATEGAN, BC 1986. Reader clues in the text of Galatians. (Referaat gelewer voor die Suid-Afrikaanse Vereniging vir Algemene Literatuurwetenskap. Word gepubliseer in SAVAL-kongresreferate 1986.)

MALAN, C (red) 1983. Letterkunde en leser: 'n Inleiding tot lesergerigte literêre ondersoeke. Durban: Butterworths.

MICHEL, O 1978. Der Brief an die Römer. Göttingen: Vandenhoeck.

NEWMAN, BM 1983. Once again - the question of ' $\mathrm{I}$ ' in Romans 7:7-25. The Bible Translator. 34, 124-135.

NOORDMANS, O 1949. Psychologie en evangelie, in Zoeklichten. Amsterdam: HUM.

OHLHOFF, H 1986. Hoofbenaderings in die literatuurstudie, in Cloete, TT, Botha, E \& Malan, C (reds), Gids by die literatuurstudie, 31-64. Pretoria: HAUM-Literêr.

PELSER, GMM 1984. Die reformatoriese grondbeskouing van die mens as simul iustus et peccator in die lig van Rom 7:14-25. HTS 40, 92-110.

PETZER, JH \& HARTIN PJ (eds) (1986). A South African Perspective on the New Testament: Essays in honour of BM Metzger. Leiden: EJ Brill.

SCHMIDT, SJ 1981. Empirical studies in literature: Introductory remarks. Poetics 10, $317-336$.

SCHULZE, LF 1978. Geloof deur die eeue. Pretoria: NG Kerkboekhandel.

SENEKAL, J 1983. Resepsie - 'n terreinverkenning, in Malan 1983: 1-42.

SULEIMAN, Susan R 1980. Introduction: Varieties of audience-orientated criticism, in Suleiman \& Crosman 1980: 3-45.

SULEIMAN, SR \& Crosman I (eds) 1980, The reader in the text: Essays on audience and interpretation. Princeton: Princeton University Press.

TODOROV, T 1980. Reading as construction, in Suleiman \& Crosman 1980: 67-82.

TOMPKINS, JP 1980. Reader-response criticism: From Formalism to Post-structuralism. Baltimore: The Johns Hopjkins University Press.

VAN DEN BERG, BHJ 1986. Die drielesingteorie van Jauss met besondere verwysing na die gelykenis van die deurwagter in Kafka se roman Der Prozess. (Lesing gelewer voor die Taal- en Letterevereniging van die PU vir CHO. Vir publikasie voorgelê aan Tydskrif vir Literatuurwetenskap.)

WILCKENS, U 1980. Der Brief an die Römer, II. Zürich: Benziger Verlag. (EKK VI/2.)

WUELLNER, W 1985. Paul as pastor. The function of rhetorical questions in First Corinthians. (Voordrag gelewer tydens Leuvense Studiedagen. Word gepubliseer in Ephemerides Theologiae Lovaniensis LX II.) 